\title{
Towards a defensible relationship between the content of socioeconomic rights and the separation of powers: conflation or separation?
}

Book or Report Section

Accepted Version

Bilchitz, D. ORCID: https://orcid.org/0000-0001-6195-675X (2018) Towards a defensible relationship between the content of socioeconomic rights and the separation of powers: conflation or separation? In: Bilchitz, D. ORCID: https://orcid.org/0000-0001-6195-675X and Landau, D. (eds.) The Evolution of the Separation of Powers: Between the Global North and the Global South. Edward Elgar, pp. 57-84. ISBN 9781785369766 doi:

https://doi.org/10.4337/9781785369773.00009 Available at https://centaur.reading.ac.uk/94546/

It is advisable to refer to the publisher's version if you intend to cite from the work. See Guidance on citing.

To link to this article DOI: http://dx.doi.org/10.4337/9781785369773.00009

Publisher: Edward Elgar 
copyright holders. Terms and conditions for use of this material are defined in the End User Agreement.

\section{www.reading.ac.uk/centaur}

\section{CentAUR}

Central Archive at the University of Reading

Reading's research outputs online 
Towards a defensible relationship between the content of socio-economic rights and the separation of powers: conflation or separation?

\section{David Bilchitz ${ }^{1}$}

\section{INTRODUCTION: RIGHTS AND THE SEPARATION OF POWERS}

What is the relationship between the separation of powers and the content of socio-economic rights? Debates - particularly in the 1970s and 1980s - surrounded whether socio-economic rights should be included in a bill of rights and whether judges should be granted powers of judicial review over them. ${ }^{2}$ As a result of objections relating to the democratic legitimacy and competence of the judiciary in adjudicating matters in the socio-economic sphere, some countries excluded these rights from their bill of rights (Canada, for instance) whereas others included them as non-justiciable directive principles (India and Ireland). Yet, these arguments were rejected in the drafting of many modern constitutions from the late 1980s onwards particularly in the new constitutions of Latin America, Eastern Europe and Africa. Socioeconomic rights were both included within the bill of rights of these constitutions and judges were granted the power of judicial review over them.

In many of these modern constitutions, the attention then shifted to the manner in which such rights were to be interpreted and adjudicated upon by the judiciary. The same arguments that arose in the context of the constitutionalization of these rights surfaced again in debates around how judges should exercise their powers of adjudication. It was argued that judges should exercise deference and restraint when faced with cases concerning socioeconomic rights. Claims about the appropriateness of judicial involvement with socioeconomic rights have in turn influenced, in some of these countries, how judges have interpreted these rights and the legal doctrines that have been developed in that regard. Institutional concerns relating to the separation of powers have thus been allowed to play a central role in determining the very content of the fundamental rights that individuals are guaranteed in these constitutional systems. ${ }^{3}$

In this paper, I shall attempt to examine what the appropriate relationship should be between institutional concerns relating to the separation of powers and a determination of the content of fundamental rights. In the second part of this paper, I shall attempt to illustrate the manner in which separation of powers considerations have influenced the 'reasonableness' approach to the adjudication of socio-economic rights that has been adopted in the jurisprudence of the South African Constitutional Court. In the third section, I shall argue that the conflation of these two sets of concerns is unjustifiable both conceptually - where two incommensurable sets of issues are not adequately distinguished - and, normatively, in terms of the weakening of the entitlements that invariably results. Having argued against such a conflation, I shall contend in the fourth part of the paper, however, that there is indeed a relationship between the two sets of issues. Centrally important to the argument will be the claim that we must distinguish reasoning relating to fundamental rights from reasoning relating to the obligations which flow from such rights. Institutional and agent-centred

\footnotetext{
${ }^{1}$ Professor, University of Johannesburg; Director, South African Institute for Advanced Constitutional, Public, Human Rights and International Law; Secretary-General, International Association of Constitutional Law

${ }^{2}$ See, for instance, M CRAnSton, Human Rights: Real and Supposed, in Political TheOry AND THE Rights OF MAn (DD Raphael ed., 1967) and C Sunstein, Against Positive Rights, 1 EASTERn EUROPEAN CONSTitutional REVIEW 35-38 (1993).

${ }^{3}$ This problem could apply both in the case of civil and political and socio-economic rights. Since it tends to be more pronounced in the relation to the latter, I shall focus on socio-economic rights in this paper.
} 
considerations are inappropriate when constructing the substance of a constitutional entitlement; they may legitimately enter into the picture when the concrete obligations flowing from such a right are under consideration. The primacy of fundamental rights entails that, an understanding of their content is necessary in order to evaluate any reasons for the attenuation of the obligations flowing from them and the 'separation of powers' questions that may arise in this context. A substantive understanding of fundamental rights thus provides one key set of normative considerations that conditions the application of the separation of powers doctrine rather than the other way round.

\section{HOW THE CONTENT OF FUNDAMENTAL RIGHTS AND SEPARATION OF POWERS COME TO BE CONFLATED}

\section{A. The Relationship between Institutional and Content-based Objections}

There are a series of 'institutional' objections relating to the separation of powers that traditionally have been lodged against judicial involvement in socio-economic rights adjudication. ${ }^{4}$ First, there is the legitimacy concern: this involves the idea that the judiciary being an unelected body should not prescribe economic policy and budgetary allocations to a democratically elected polity. ${ }^{5}$ Where socio-economic rights impose positive obligations, these often have large budgetary implications that impact on a range of areas of governance and thus involve what are often termed 'polycentric' issues. ${ }^{6}$ To allow the judiciary to decide on such matters would essentially be to "compromise, or to pre-empt, democratic deliberation on crucial issues'. ${ }^{7}$ Secondly, there is the competency concern: since judges do not have particular expertise in economic and policy matters, it is claimed that they are ill-suited to making determinations on these issues ${ }^{8}$ and, where they do so, they are likely to make flawed judgments. ${ }^{9}$

A second strand of objections relates to a different problem and that involves determining the content of these rights and the duties that flow from them. This may be

\footnotetext{
${ }^{4}$ See generally for an outline of these concerns and responses to them, M Pieterse Coming to Terms with the Judicial Enforcement of Socio-Economic Rights, 20 South AfRICAN Journal OF HuMAN Rights 390-392 (2004).

${ }^{5}$ See D Davis, The Case Against the Inclusion of Socio-economic demands in a Bill of Rights Except as Directive Principles, 8 South AFriCAN JouRnal OF Human Rights 489 (1992).

${ }^{6}$ Fuller famously argued that legal adjudication cannot successfully deal with 'polycentric' tasks: see L Fuller, The Forms and Limits of Adjudication, 92 HARVARD LAW REVIEW 394ff (1978). However, most legal disputes that involve any budgetary expenditure involve some degree of polycentricity. For a critique of Fuller's approach, see J.W.F. Allison, Fuller's Analysis of Polycentric Disputes and the Limits of Adjudication, 53 CAMBRIDGE LAW JOURNAL 367-383 (1994).

${ }^{7}$ C Sunstein, Designing Democracy: What Constitutions Do 224 (Oxford University Press, 2001) and C Scott \& P Macklem, Constitutional Ropes of Sand or Justiciable Guarantees? Social Rights in a New South African Constitution, 141 University OF PenNSYlvania Law Review 18-23 (1992).

${ }^{8}$ See Minister of Health v Treatment Action Campaign 2002 (5) SA 721 (CC) (Treatment Action Campaign) at para 38. See Scott \& Macklem id at 23-24.

${ }_{9}^{9}$ The United States courts have used problems of judicial competence to avoid deciding matters that involve direct budgetary implications. See San Antonio Independent School District v. Rodriguez., 411 U.S 1, 31 (1973) at 41 where it stated that the Court 'did not possess the expertise and familiarity with local problems so necessary to the making of wise decisions with respect to the raising and disposition of public revenues. See also M Kende, The South African Constitutional Court's Embrace of Socio-Economic Rights: A Comparative Perspective, 6 Chapman Law Review 154-155 (2003); E Mureinik, Beyond a Charter of Luxuries: Economic Rights in the Constitution. South African Journal of Human Rights, 8 SOUTH AFRICAN Journal OF Human RigHTS 468 (1992) and, generally, M Pieterse supra note 4 above at 392-396; A Sachs, Social and Economic Rights: Can They be Made Justiciable?, 53 SOUTHERn MeTHOdist University LAW REVIEW 1388 (1999).
} 
referred as the 'indeterminacy concern': it is argued that these rights are 'inherently vague and indeterminate, and that they do not, therefore, lend themselves to judicial enforcement' ${ }^{10}$ The first part of this challenge relates to the very nature of these rights and our ability to understand what they in fact entail. The fact that these rights have only recently been placed in constitutions in many countries, means that there is only a short history of judicial decision-making in this area. Limited theorising until recently concerning their content has led to the charge of greater indeterminacy in respect of socio-economic rights than in relation to civil and political rights. ${ }^{11}$ The charge relating to content, however, has often been connected with the two institutional concerns articulated above. To render the rights more determinate and concrete would, it is often thought, involve making the duties and obligations they impose more explicit. It is feared that, doing so, would lead the judiciary to usurp the powers of other democratically-elected branches of government and to go beyond the core of their competences. Thus, where judges are granted powers to interpret such rights, it has been argued that they should do so in a restrained manner that does not remove the indeterminacy of these rights: that will enable judges to retain the flexibility necessary to avoid cases where the two institutional concerns suggest that the judiciary should not interfere. $^{12}$

\section{B. The Conflation of Content and Separation of Powers in the Jurisprudence of the South African Constitutional Court}

These claims have been influential and affected the manner in which judges have approached the task of adjudicating cases in relation to socio-economic rights. We find in the jurisprudence that judges have often sought to avoid determining the content of such rights and where they have done so, often institutional concerns have guided the approach they have adopted. ${ }^{13}$ This process of conflating institutional considerations relating to the separation of powers with content is clearly in evidence in the approach to socio-economic rights adopted by the South African Constitutional Court.

Consider the first case where the court had to consider expressly a socio-economic rights provision, namely, Soobramoney $v$ Minister of Health (Kwazulu-Natal). ${ }^{14}$ The case concerned the claim by a patient suffering from chronic renal failure that the state had a duty

\footnotetext{
${ }^{10}$ See Mureinik supra note 9 above at 467. See also Scott \& Macklem supra note 7 above at 44-45

${ }^{11}$ Id Scott \& Macklem at 72-73. Some, however, regard the criticism as an inherent philosophical problem with socio-economic rights: for one of the older classical expressions of this critique (see Cranston, supra note 9). For some thoughtful and convincing replies, see R Plant, Social and Economic Rights Revisited, 14 KINGS COLLEGE LAW JOURNAL $1 \mathrm{ff}$ (2003).

12 See, for instance, C Steinberg, Can Reasonableness Protect the Poor? A Review of South Africa's SocioEconomic Rights Jurisprudence, 123 SOUTH AFRICAN LAW JouRnAL 264 (2006) who argues that '[d]efining the content of socio-economic rights...necessarily and inevitably draws the court into formulating, rather than evaluating, policy". For a recent proponent of a similar type view, see J KING, JUdGING SocIAL RIGHTS (Cambridge, 2012).

13 For a consideration of some of the comparative examples of this phenomenon, see D BILCHITZ, Constitutionalism the Global South and Economic Justice, in Constitutionalism of the Global South: THE Activist Tribunals of India, South Africa And Colombia (D Bonilla Maldonado (ed), 2013). This problem goes beyond the socio-economic rights context alone and institutional considerations appear often to have impacted upon the content the court gives to rights themselves: for instance, in the majority judgment in New National Party of South Africa v Government of the Republic of South Africa 1999 (3) SA 191 (CC), separation of powers impacts upon the standard of review against which national legislation is evaluated in determining whether an infringement of the right to vote has taken place. At times, the court appears to recognise the need to separate out rights analysis from institutional considerations (see for instance Treatment Action Campaign supra note 8 at para 99) though the doctrine it applies in that very case arises from a conflation of these two issues (as I argue below).
}

141998 (1) SA 765 (CC). 
to provide him with renal dialysis. The applicant made his claim in terms of the obligations of the state that flow from the right to life in the Constitution and the right not to be refused emergency medical treatment. The court did not focus on these rights but rather centred its analysis on the right to have access to health care services. The right reads as follows:

\section{Section 27 (Health-care, food, water and social security)}

(1) Everyone has the right to have access to-

(a) health care services, including reproductive health care;

(b) sufficient food and water; and

(c) social security, including, if they are unable to support themselves and their dependants, appropriate social assistance.

(2) The state must take reasonable legislative and other measures, within its available resources, to achieve the progressive realisation of each of these rights.

No one may be refused emergency medical treatment.

As can be seen from the structure of section 27 itself, the first sub-section outlines the entitlement. Section 27(2) then goes on to specify the contour of the state's obligations in relation to these rights and the third sub-section provides a specific claim not to be refused emergency medical treatment. In addressing the section 27(1)(a) right for the first time, it could have been expected that the court would have said something about the scope of the protections it offers. Instead, however, the court moved directly to consider the question as to whether the state had the available resources to make renal dialysis available to all those similarly situated to Mr Soobramoney. In this respect, it marshalled some of the evidence presented to it but finally held that '[a] court will be slow to interfere with rational decisions taken in good faith by the political organs and medical authorities whose responsibility it is to deal with such matters. ${ }^{15}$

As has been noted by several authors, ${ }^{16}$ Soobramoney was an early, difficult case that the court was confronted with and it chose to adopt a highly deferential approach, indicating that it would respect the 'rational' decisions of other decision-makers (which involves a minimal standard of review). Importantly, very little consideration was given to the rights of the individual concerned: the emphasis and focus of the judgment was on the resources available for dialysis and the question as to who should legitimately make the hard rationing decisions in this regard.

The court's approach shifted somewhat with the next ground-breaking case of Grootboom $v$ the President of the Republic of South Africa ${ }^{17}$ That case concerned a group of individuals who were living on a field with only plastic sheeting to cover them. They claimed before the Court that they were entitled to basic shelter in terms of the right to have access to adequate housing in the South African Constitution (section 26(1)). The Court famously adopted its 'reasonableness approach' to socio-economic rights in this case: the central enquiry at the heart of this approach involves the court evaluating whether legislation, policy or conduct of the government in relation to a particular socio-economic right meets the

\footnotetext{
${ }^{15} I d$ at para 29.

${ }^{16} \mathrm{C}$ Scott \& P Alston, Adjudicating Constitutional Priorities in a Transnational Context: a Comment on Soobramoney's Legacy and Grootboom's Promise, 16 South AfRICAN Journal of Human Rights 242 (2000) and D Moellendorf, Reasoning about Resources: Soobramoney and the Future of Socio-Economic Rights Claims, 14 SOUTH AFriCAN JOURNAL OF HUMAN RightS 331 (1998).

17 2001(1) SA 46 (CC).
} 
standard of 'reasonableness'. ${ }^{18}$ The court considered an alternative approach knowns as the 'minimum core' which would have required it to determine a minimum core content of the right which is accorded a strong weight in judicial reasoning. It rejected this approach to determining the content of such rights largely on the basis that it lacked the information to determine the minimum core in the case before it. It, however, left open the question of the suitability of such an approach to the adjudication of socio-economic rights more generally by stating that '[it is not in any event necessary to decide whether it is appropriate for a court to determine in the first instance the minimum core content of a right' ${ }^{19}$ Clearly, the court here links determining the minimum core content of a right to the question whether it is 'appropriate' for a court to determine that content: the latter question involves institutional considerations relating to the separation of powers concerning which branch of government is best situated to determine the content of rights. The court then went on to outline what is involved in determining the reasonableness of a measure and reached the conclusion that the government's housing programme was not reasonable in that it failed to cater to those in desperate need.

As several academic commentators have pointed out, the reasonableness approach has been described as an 'administrative law model of socio-economic rights' ${ }^{20}$ Administrative law allows courts to engage in an evaluation of the decisions of administrative agencies whilst retaining a sense that there is a margin of appreciation allowed to such an entity to take the decision in question. As one writer puts it, 'a special attraction of this position is that it protects against arbitrariness while it also recognises the democratic pedigree of the agency and the simple fact of limited resources'. ${ }^{21}$ The reasonableness approach requires other branches of government to provide reasons for their decisions in the socio-economic sphere which, in turn, has certain salutary effects on laws and policies such as accountability and improving decision-making. ${ }^{22}$ The reasonableness approach, it is claimed, is also flexible and allows judges to tailor their interventions to cases where they have both the legitimacy and competence to intervene. ${ }^{23}$

The institutional basis for the reasonableness approach becomes even more apparent in the Treatment Action Campaign case. That case concerned the constitutionality of a government programme to prevent the mother-to-child transmission of HIV/AIDS which made available an anti-retroviral drug - known as nevirapine - only at specific health-care facilities in South Africa (which effectively prevented universal access). The government raised a number of separation of powers concerns in its arguments that sought to justify its policy. The court held that, whilst these were not relevant to the justiciability of these rights, they affected 'the manner in which a court should exercise the powers vested in it under the

\footnotetext{
${ }^{18}$ Id at para 33. The court has also outlined certain characteristics (between paras 39-44) that a 'reasonable' programme would exhibit which include the following: a reasonable programme must (1) ensure that 'the appropriate financial and human resources are available'; (2) 'must be capable of facilitating the realisation of the right'; (3) must be reasonable 'both in its conception and their implementation'; (4) must be flexible; (5) must attend to 'crises'; (6) must not exclude 'a significant segment' of the affected population; and (7) must balance short, medium and long-term needs.

${ }^{19} I d$.

${ }^{20}$ C Sunstein, Social and Economic Rights? Lessons from South Africa, 11 ConstiTUTIONAL FoRUM 123 (2001) and D Bilchitz, Giving Socio-Economic Rights Teeth: The Minimum Core and Its Importance, 119 SOUTH AFRICAN LAW JOURNAL 495 (2002).

${ }^{21}$ Id Sunstein.

${ }^{22}$ See Mureinik supra note 9 above at 473. See also, E Mureinik, A Bridge to Where? Introducing the Interim Bill of Rights, 10 SOUTH AFRICAN JOURNAL OF HUMAN RigHTS 31 - 48 (1994)

23 Steinberg supra note 12 above at 276-283. See ALSO S LIEBENBERG, Socio-ECONOMIC RIGHTS: ADJUDICATION UNDER A TRANSFORMATIVE CONSTITUTION 163-187 (2010).
} 
Constitution' ${ }^{24}$ The court once again was seized with the question of whether to introduce the notion of minimum core obligations into its jurisprudence on socio-economic rights. In rejecting the invitation to do so, it stated that courts are not 'institutional equipped to make the wide-ranging factual and political enquiries necessary for determining what the minimum-core standards...should be, nor for deciding how public revenues should most effectively be spent'. ${ }^{25}$

The court went on to reflect on its role in socio-economic rights cases which led it to the conclusion that there is no independent content to the socio-economic rights in the South African constitution (contained in section 26(1) and 27(1)) separate from the provisions concerned with limiting state obligations (sections 26(2) and 27(2)). It states as follows:

Courts are ill-suited to adjudicate upon issues where court orders could have multiple social and economic consequences for the community. The Constitution contemplates rather a restrained and focused role for the courts, namely, to require the state to take measures to meet its constitutional obligations and to subject the reasonableness of these measures to evaluation. Such determinations of reasonableness may in fact have budgetary implications, but are not in themselves directed at rearranging budgets. In this way the judicial, legislative and executive functions achieve appropriate constitutional balance. ${ }^{26}$

The court continued in an even clearer exposition to link institutional considerations to the determination of the content of a socio-economic right in Mazibuko $v$ City of Johannesburg. ${ }^{27}$ The part of the case relevant to this paper concerned a challenge to the constitutionality of the amount of water provided by the City of Johannesburg at no charge to every resident of the city (known as the free basic water allowance) on the basis that it was insufficient to meet the needs of individuals in a particular poor urban community. The court refused to provide any determination of the amount of water that individuals were entitled to in terms of the right to have access to sufficient water (section 27(1)(b) of the constitution). Its reasons for doing so related to a narrow, textual interpretation of the constitution together with more substantive reasons relating to the separation of powers. In relation to the latter, O'Regan J (writing on behalf of a unanimous court) stated the following:

[O]rdinarily it is institutionally inappropriate for a court to determine precisely what the achievement of any particular social and economic right entails and what steps government should take to ensure the progressive realisation of the right. This is a matter, in the first place, for the legislature and executive, the institutions of government best placed to investigate social conditions in the light of available budgets and to determine what targets are achievable in relation to social and economic rights. Indeed, it is desirable as a matter of democratic accountability that they should do so for it is their programmes and promises that are subjected to democratic popular choice. ${ }^{28}$

O'Regan J continues to write that this approach entails that, in the first instance, the duty lies upon the legislature and executive to take measures to realise socio-economic rights. 'By

\footnotetext{
${ }^{24}$ Treatment Action Campaign supra note 8 at para 22.

${ }^{25} I d$ at para 37.

${ }^{26}$ Id at para 38 (my emphasis).

272010 (4) SA 1 (CC).

${ }^{28}$ Id at para 60 (my emphasis).
} 
adopting such measures, the rights set out in the Constitution acquire content, and that content is subject to the constitutional standard of reasonableness. ${ }^{29}$

Mazibuko is often considered as the high-water mark of the Constitutional Court's deference to other branches in cases concerning socio-economic rights. ${ }^{30}$ What it renders clear, however, is that the court's adoption of an approach to the adjudication of socio-economic rights which focuses on the reasonableness of measures adopted by other branches - and which avoids providing substantive content to these rights - is clearly drawn from a particular vision of the separation of powers. This approach to adjudicating constitutional rights is thus derived from an understanding of the appropriate role of differing institutions in the constitutional scheme. Whether this link is justifiable and the relationship between the content of rights and the separation of powers is the subject of the next section.

\section{WHY WE SHOULD NOT CONFLATE CONTENT AND INSTITUTIONAL CONCERNS}

In order to understand whether the connection between the determination of content and separation of powers concerns highlighted above is justifiable, it is important first to have an understanding of the normative foundations and conceptual architecture of fundamental rights as well as the 'separation of powers' doctrine. Doing so, I argue, will provide us first with an understanding as to why the two sets of issues should not be conflated but also begins the process of sketching the contours of the relationship between them.

\section{A. A brief examination of the normative underpinnings of fundamental rights and the separation of powers}

At international law and in many constitutions, fundamental rights are generally understood to be rooted in the foundational notion of the 'dignity' of every individual. ${ }^{31}$ Dignity is usually understood to involve the idea that every individual has an equal worth or importance. As such, individuals with dignity are entitled to be treated with respect for their equal worth: such respectful treatment can be understood to require recognising a range of fundamental entitlements which protect the individual's freedom to pursue their life goals and ambitions and to have the general resources necessary to be in a position to do so. ${ }^{32}$

This brief account of the justification underlying fundamental rights highlights certain key features of the concept. First, it is focused on providing certain entitlements or guarantees to a class of individuals who have worth. There is some dispute as to how this class is

\footnotetext{
${ }^{29}$ Id at para 56.

${ }^{30}$ Liebenberg supra note 23 above at 466-480; see also R Kapindu, Pulling Back the Frontiers of Constitutional Deference: Mazibuko \& Others $v$ City of Johannesburg \& Others - a Jurisprudential Setback, 25(2) SOUTHERN AFriCAN PUBliC LAW JOURNAL (SAPL) 471-490 (2010).

${ }^{31}$ See, for instance, Article 1 of the German Constitutiona and the International Covenant on Civil and Political Rights available at http://www.ohchr.org/en/professionalinterest/pages/ccpr.aspx.

32 There are of course various justifications that have been provided for fundamental rights and I seek merely here to sketch an approach that would be recognizable in many constitutional systems: for a more developed justification of fundamental rights, see D BILCHITZ, POVERTY AND FundAMENTAL RIGHTS (2007). For other approaches, see C FABRE, Social Rights in the Constitution (2001); J GRIFFin, On Human Rights (2008); and K Moller, The Global Model of Constitutional Rights (2012).
} 
constituted and whether it extends to some non-human animals ${ }^{33}$ : in general, though, it is accepted that all human beings, at least, are entitled to these rights. The focus of fundamental rights discourse is importantly on the beneficiaries of the rights and ensuring that they are provided with the freedom and resources these rights guarantee to them.

Secondly, one of the features of rights discourse is that it leaves open the agents who are responsible for realising these guarantees. Though this is sometimes highlighted as a criticism of fundamental rights thinking in that it fails to specify the agents responsible for giving effect to these guaranteees, ${ }^{34}$ it may also be regarded as one of its benefits: rights discourse includes an in-built flexibility concerning the agents responsible for realising rights. This feature of rights has become of particular importance in the modern world where there are multiple agents that can affect such rights including states, corporations, nongovernmental organisations and individuals.

Finally, rights involve entitlements to be provided with certain goods - broadly understood to fall under notions of 'freedom' and 'resources' - which are required to ensure the protection of fundamental interests that all individuals share. In ensuring those goods are provided, a range of varied actions may be required including both negative obligations of non-interference as well as positive obligations to take concrete actions to realise these rights. ${ }^{35}$ From the perspective of fundamental rights, though, what matters is essentially ensuring that the fundamental interests of individuals that underpin each right are given adequate protection. Thus, human beings have a fundamental interest in having, at least, shelter from the elements in conditions that will not be harmful to their health. Concretely, this requires ensuring specific goods, namely, that individuals be guaranteed at least a space in which to exist with a top structure that provides protection from elements and services necessary to maintain the hygiene of this environment.

Having outlined some key features of rights discourse, it is now important to highlight briefly some of the underpinnings of the doctrine of separation of powers. Whilst the idea has ancient origins, the modern doctrine can be traced to several thinker - John Locke, Charles Baron D Montesquieu and James Madison - who were concerned to address the tendency of state power to be exercised in a tyrannical manner. ${ }^{36}$ The problem they were all concerned about related to the fact that that the concentration of too much state power in one individual or institution tended towards abuse. ${ }^{37}$ To address this problem, it was suggested that state power be diffused between several different branches, each with its own specific function: the legislature would make laws, the executive would give effect to them and the judiciary would adjudicate upon disputes surrounding these laws. Since there would unavoidably be an overlap, at times, between the functions, a system of checks and balances between the branches would help avoid the over-concentration of power and ensure each realised in the main its own function. ${ }^{38}$ Moreover, particularly in a modern administrative state, the notion of separation of powers can also be defended on the basis of efficiency. The argument would

\footnotetext{
${ }^{33} \mathrm{I}$ am of the view that they are. See D Bilchitz, Moving beyond arbitrariness: the legal personhood and dignity of non-human animals, 25 South African Journal of Human Rights 38ff (2009). See also T Regan, The CASE FOR ANimal Rights (1984) and M NusSBAum, FrontiERS OF JUSTICE (2006) at 346ff.

${ }^{34}$ O O’NeILL, TOWARDS JusticE AND VIRTUE (1996) at 133-136.

${ }^{35} \mathrm{H}$ SHUE, BASIC RIGHTS (1980) at 52 has argued convincingly that each right involves at least three forms of obligation which I elaborate upon further below. See also S FrEDMAN, HuMAn RightS TranSFORMED (2008) at 98.

${ }^{36}$ For an overview of the historical development of this idea, see S SEEDORF \& S Sibanda, Separation of Powers in Constitutional Law of South Africa (S Woolman et al (eds), 2006) 12-3 to 12-10. See also, for instance, A Hamilton ET AL,. The FEDERAList PAPERS 235-257 (1787, 2014 ed)

${ }^{37} I d$.

${ }^{38} I d$ at $12-11$ to $12-12$.
} 
be that creating separate branches allows for different facets of government to develop particular expertise which ultimately helps improve the system of governance overall. ${ }^{39}$

\section{B. The Problems with Conflating Fundamental Rights and the Separation of Powers}

On the face of it, the notion of fundamental rights and the doctrine of the separation of powers appear to be completely different in nature and seek to address different features of a constitutional system. Fundamental rights specify what any decent community must provide to individuals who have an equal dignity and thus address at least a minimum substantive conception of what constitutes justice in a political community. They thus involve specifying 'what' individuals may legitimately claim at a minimum from a political community. Separation of powers, on the other hand, is concerned with avoiding the over-concentration of power, the division of labour between different branches of government and what is best placed within these different spheres. It is very much about 'who' within a state must perform particular tasks.

Of course, if rights set the substantive vision of distributive justice in a political community, then, to a large extent, the very division of labour represented by the separation of powers must be focused on realising them. Yet, even here, there seems to be a clear distinction between different sets of concerns: rights focus on 'what' must be provided to 'whom' (a set of beneficiaries); whereas separation of powers concerns the agents ('who') within the state that are obligated to provide the substance of rights to these beneficiaries. It also requires a specification as to which agents are required to perform particular tasks.

It is difficult to see why and how the 'who' question - the agents or institutions within a state tasked with realising rights - can determine the 'what' question - what must be guaranteed to individuals. Indeed, the South African Constitutional Court precisely seems to approach the matter the wrong way round: it utilises the 'who' question concerning which agents must avoid threatening rights (and help implement them) to avoid determining 'what' must be protected or implemented. These are surely different questions which must be answered separately: the entitlements of individuals rest upon notions of their fundamental interests that require protection and do not depend at all upon understanding who the appropriate agents are to realise these entitlements. To invoke questions of the appropriate agents in determining the very scope of fundamental entitlements, is to conflate two distinct sets of issues and to undermine a clear-headed determination of what rights in fact protect.

Indeed, it might well be contended that the relationship in fact should be the other way round: it appears necessary to answer the question as to 'what' fundamental rights require in order to understand which agents (the 'who' question) within the state are best placed to give effect to those rights. If fundamental rights are the basic conditions of substantive justice outlined in a constitution, then they should be the guiding principles which underpin the operation of the separation of powers doctrine rather than the other way round. It is strange that this point has often been forgotten in the context of socio-economic rights as the traditional justification of the separation powers itself saw the doctrine as a means to protect the substantive goals of ensuring that the liberty of individuals was not threatened through the abuse of power by state institutions. ${ }^{40}$

The argument thus far would suggest that, whoever is responsible for interpreting rights should not conflate the substance of rights with separation of powers considerations.

\footnotetext{
${ }^{39}$ N W Barber, Prelude to the Separation of Powers, 60 CAMBridge LaW Journal 59 (2001); M.J.C. VILE, CONSTITUTIONALiSM AND THE SEPARATION OF POWERS (1967) at 16.

${ }^{40}$ Seedorf \& Sibanda supra note 36 at 12-5ff and Hamilton et al supra note 35 at 253.
} 
The conflation of content and institutional considerations, is also undesirable as it is usually accompanied by a weakening of fundamental rights. The content of rights becomes detached from its relationship to the fundamental interests of individuals. Instead, a whole host of factors relating to the appropriate institutional setting for realising these rights helps determine the approach to developing their content and thus attenuates the primary focus on the interests of individuals. As such, it becomes possible to overlook harms to individuals whilst focusing on the more detached considerations relating to the separation of powers.

Consider the Mazibuko case of the Constitutional Court of South Africa: the court hardly engages at all with the severe harms suffered by individuals who lacked access to water in the affected community. Evidence was led in the papers about the fact that many individuals in that community were suffering from HIV/AIDS which led to their need for more water for hygienic purposes and because they needed to use the toilet more frequently. ${ }^{41}$ The urban community in question also had toilets which involved flushing water to render them clean which utilises a larger amount of water than sanitary systems in rural communities which do not function on this basis. As a result, the free basic water allowance was not sufficient to meet the needs of individuals in these communities to live in sanitary conditions. It was clear therefore that the lack of sufficient water affected the health, sanitation and dignity of the individuals concerned yet that issue was largely ignored by the constitutional court. The reason for this is not difficult to understand: the entire focus of the court's approach to socio-economic rights has been on the 'reasonableness' of the government's actions which deflects attention from the harms suffered by the individuals to their fundamental interests.

The reasonableness approach highlights the perils of conflating content and institutional concerns. Where content is determined through institutional considerations, it is not possible to ascertain with any clarity what protections these rights offer for particular interests. That, in turn, leads to the significant weakening of these protections. ${ }^{42}$ Institutional solutions to socio-economic rights enforcement can only be developed if it is understood first what they are designed to achieve. ${ }^{43}$ It is thus necessary to have a conception of the content of socio-economic rights independently of these institutional considerations.

\section{DRAWING THE RELATIONSHIP BETWEEN THE CONTENT OF RIGHTS AND THE SEPARATION OF POWERS}

Whilst I have argued against conflating questions of the content of socio-economic rights with separation of powers concerns, there is an interesting relationship between the two. In this section I seek to chart the relationship first by highlighting a flaw in the reasoning of the SA Constitutional Court and some academic authors which has already been alluded to. The flaw is central in that it allows us to capture the manner in which we need to separate the

\footnotetext{
${ }^{41}$ This played an important part in the reasoning of the High Court: see $S v$ Mazibuko [2008] ZAGPHC 106

42 O Fiss, Foreword: The Forms of Justice, 93 HARVARD LAW REVIEW 55 (1979) states that judges, in striving to give remedies that they believe to be efficacious and appropriate to their role may 'tailor the right to fit the remedy'. The South African court's approach outlined above provide evidence of this trend which in the process weakens socio-economic rights protections.

${ }^{43}$ In the context of the manner in which the separation of powers is designed, Barber supra note 39 above recognizes that '[s]eparation of powers is a theory of the ordering of collective action; it must be prefaced by a political theory if it is to possess any normative force' (at 63) and ' $[t]$ houghts about the proper aims of collective action influence the type of institution that should exist and the tasks assigned to it' (at 67). Institutional design thus requires a sense of the ends sought to be realized by those institutions and one of the most important of these ends is the realization of fundamental rights.
} 
content of rights and the separation of powers as well as the point at which they come into relationship with one another.

\section{A. Differentiating between Rights and Obligations}

The understanding adopted of the relationship between rights and duties, is of central importance in resolving the relationship between the content of rights and separation of powers concerns. Logically, it has been asserted that there are relationships of correlativity between rights and duties: if I have a claim right to be free from X, then there is a duty upon agents not to subject me to $\mathrm{X} .{ }^{44}$ Such reasoning, whilst formally correct is not very helpful in constructing the duties that flow from rights in in modern constitutions which tend to be formulated in a very abstract form such as 'everyone has the right to freedom of expression'. No doubt such a right imposes a duty on various agents to realise the right to freedom of expression: if we, however, are to achieve a helpful specification of what this entails, we need to recognise that the broad abstract rights in constitutions give rise to a range of more specific duties. ${ }^{45}$ Thus, the right to freedom of expression may impose duties not to interfere with an individual's expression, for an individual to be protected from the interference of third parties with their expression and to be provided actively with the conditions necessary to ensure that they can express themselves and have the platforms to do so. ${ }^{46}$ Whilst this specification helps provide a more concrete understanding of the implications of rights for agents, it is important to recognise that the relationship between rights and duties does not imply conceptual equivalence between the two notions.

Rights, as has already been outlined, seek to provide an understanding of the entitlements a beneficiary can claim in order to protect a fundamental interest that $\mathrm{s} / \mathrm{he}$ has. The perspective from which rights are claimed is that of the beneficiary and what matters is that the entitlement is provided to him/her. Duties, on the other hand, embody an agentfocused perspective: what matters, in this regard, is that a particular agent fulfils the obligations that are placed upon him/her. ${ }^{47}$ Clearly, in order to realise an entitlement, there must be some understanding of the agents responsible for doing so. Yet, the fact that, in most constitutional systems, fundamental rights are the focus has a number of important implications. What must remain primary in these systems is the individual beneficiary and his/her entitlements: the duties of agents are specified in relation to the fulfilment of these entitlements. The primacy of rights thus requires a clear conception to be articulated of the nature of the entitlements that are guaranteed which then helps to specify the obligations that agents must assume. The allocation of obligations amongst various agents is a further step that must be taken once an understanding of these obligations is arrived at and a determination can be made as to which agent is best placed (and most appropriate) to fulfil these tasks.

\section{B. The Problematic Conflation of Rights and Obligations}

These points may seem to be rather foundational and at the very heart of rights discourse: yet, it is instructive to examine the way in which they often fail to be recognised by courts and academic authors alike. First, let us turn once again to the jurisprudence of the South African

\footnotetext{
${ }^{44}$ See M Kramer et Al,. A DebAte Over Rights (1998) at 7-60 for an examination of the logical correlative relationships that exist in Hohfeld's schema of rights, duties, powers and liabilities.

${ }^{45}$ See, for instance, H SHUE, BASIC RighTs (1980) at 52.

46 The duties discussed correspond to the typology of duties outlined by Shue and that are now accepted in international human rights law as duties to 'respect, protect, and fulfil'.

${ }^{47}$ See, for instance, Bilchitz supra note 32 at 74.
} 
Constitutional Court in relation to socio-economic rights. What is evident from a close examination of the judgments is that the court spends very little time examining the rights themselves and the nature of the interests protected by the rights. Instead, it moves almost immediately in many of its judgments to a focus on the obligations of the state.

Consider, first the Soobramoney case: the court, in outlining its approach to interpreting the health-care right, immediately writes that ' $[\mathrm{w}]$ hat is apparent from these provisions is that the obligations imposed on the state by sections 26 and 27 in regard to access to housing, health care, food, water and social security are dependent upon the resources available for such purposes, and that the corresponding rights themselves are limited by reason of the lack of resources' (my emphasis) ${ }^{48}$. This quote places obligations first in its reasoning and construes rights in light of these obligations rather than the other way round. The court's conclusion bears out this finding in that its focus is on the constitutional duty of the state 'to comply with the obligations imposed on it by section 27 of the Constitution. It has not been shown in the present case, however, that the state's failure to provide renal dialysis facilities for all persons suffering from chronic renal failure constitutes a breach of those obligations' (my emphasis). ${ }^{49}$

A key feature of the court's approach in subsequent socio-economic rights jurisprudence that leads it to focus largely on the reasonableness of the actions of the state lies in its finding that that the rights (expressed in sections 26(1) and 27(1)) must essentially be read in light of the qualifications on the state's obligations outlined in sections 26(2) and 27(2). ${ }^{50}$ This is expressed most clearly in the Treatment Action Campaign case where the court holds that:

Sections 27(1) and 27(2) must be read together as defining the scope of the positive rights that everyone has and the corresponding obligations on the state to "respect, protect, promote and fulfil" such rights. The rights conferred by sections 26(1) and 27(1) are to have 'access' to the services that the state is obliged to provide in terms of sections $26(2)$ and $27(2) .{ }^{51}$

The relationship between rights and obligations is further engaged expressly in the Mazibuko case. The flawed approach in the judgment can perhaps be traced to the starting point articulated in this paragraph:

It will be helpful to start by considering the relationship between section 27(1)(b) and section 27(2) of the Constitution. In section 27(1), the Constitution creates a right of access to sufficient water. As with all rights, to understand the nature of the right, we need to understand the nature of the obligations imposed by it. What obligations does it impose and upon whom $?^{52}$

As we see in the latter quote, the court essentially renders obligations primary in interpreting rights and thus essentially undermines the fact that our constitution places the focus on the realisation of fundamental rights. The court seems to think that there is a simple conceptual equivalence between rights and obligations: yet, has I have argued above, that is not correct.

\footnotetext{
48 Soobramoney supra note 14 above at para 11.

${ }^{49}$ Id at para 36.

${ }^{50}$ See, for instance, Grootboom supra note 17 above at para 34 and Treatment Action Campaign supra note 8 at para 23.

${ }^{51}$ Id Treatment Action Campaign supra note 8 above at para 39.

${ }^{52}$ Mazibuko supra note above at para 46.
} 
Rights and obligations have different foci and rendering one or the other primary has important implications.

Before examining these implications, I would like to point out the existence of similar reasoning in the recent book by Jeff King on the adjudication of social rights. He importantly distinguishes between the scope of an interest protected by a right and the nature of the obligation in respect of such an interest. He contends, however, that 'the scope of the interest in receiving the social minimum is not the crucial aspect of what judges would be called upon to specify'. ${ }^{53} \mathrm{He}$ goes on to state that the crucial question for judges 'is whether the state has satisfied a general obligation'. ${ }^{4} \mathrm{He}$ concludes that courts will generally be required to adjudicate whether the state has provided acceptable justifications in favour of a particular policy rather than 'with the scope of interests' of individuals. ${ }^{55} \mathrm{King}$, here, once again can be seen to place obligations-orientated reasoning at the heart of the adjudication of fundamental rights. As such, separation of powers questions become primary for him which leads him to advocate for an approach to adjudication which places these concerns at its heart (requiring judges to adopt an incremental approach to social rights adjudication). ${ }^{56}$ The content of fundamental rights is not primary in his conception and thus, it is likely on his approach, that institutional concerns relating to the separation of powers will heavily influence the content judges give to fundamental rights. ${ }^{57}$

What we have seen in this section is that the task of adjudicating socio-economic rights is conceived of by some courts and academics as a matter of the construction of the state's concrete obligations to realise these rights. In doing so, they essentially place duties at the centre of the adjudicatory process. Since duties are agent-centred, it becomes understandable why concerns about the appropriate agents to realise these rights become central to these theories. I have argued, however, that constitutions do not include a statement of duties but a bill of rights: as such, the conceptual reasoning underpinning rights should be the focus of judicial interpretation. If this is so, it is inappropriate to bring in questions of the appropriate agents for the fulfilment of obligations into the very construction of rights themselves. If we accept this point, however, how far does it take us? What are the implications for the relationship between rights, duties and separation of powers considerations in adjudication? And what difference does it make in the adjudication of fundamental rights? These questions are the subject of the next section.

\section{Capturing the relationship between rights, obligations and the separation of powers}

Let us imagine the judiciary is faced with adjudicating a case that is brought by Juana who is unable to feed herself. She claims that there has been a violation of her right to sufficient food. An approach that focuses on the primacy of rights first is required to understand

\footnotetext{
${ }^{53}$ KING supra note above at 117.

${ }^{54} \mathrm{Id}$.

${ }^{55} \mathrm{Id}$.

${ }^{56}$ As will be seen, obligations are of course part of the adjudication of such rights so the reasoning in this paper does not automatically exclude King's arguments for an incremental approach to adjudication surrounding the ultimate obligations upon the state. The approach does, however, require much more attention to the content of fundamental rights which cannot be avoided if there is to be any meaningful social rights jurisprudence at all.

${ }^{57}$ This is a worry I also have with the balancing approach towards the competence of the judiciary advocated for recently in M Klatt, Positive Rights: Who Decides? Judicial Review in Balance. 13 INTERNATIONAL JOURNAL OF CONSTITUTIONAL LAW 354 (2015). Klatt does not indicate how in Adjudication the two enquiries of balancing competences and substantive normative conflicts will work, leading to the worry that judges will not perform two separate balancing enquiries and conflate the two sets of concerns.
} 
whether Juana falls within the class of rights-bearers; and, secondly, what she is entitled to claim. The first question would be answered rather easily given that the right is usually understood to apply to all human beings. The second question is more complex, however: it would require, on the suggested approach, specifying the key interests protected by the right and whether or not Juana's interests fall within those protected by the right. If Juana was starving, it would be hard to see how any meaningful understanding of this right could exclude her from its ambit. Juana could be surviving but exhibiting symptoms of malnutrition and negative health effects from a lack of adequate food both in terms of the quantity available to her and its quality. Courts would need to consider whether the right to food also guarantees individuals the ability to claim sufficient food that will not lead to these health effects if they are unable to provide it for themselves. In so doing, the court would have to specify standards as to the level of provision guaranteed by the right. Should Juana lack this level of provision and be unable to provide it herself, the right could be said to be infringed at a prima facie level.

That, however, would not end the enquiry. The court would need to grapple with what these standards require of various agents who have the responsibility to realise the right. A correlative obligation would immediately be recognised on these agents to meet the standards that flow from the right itself. At this stage, courts would need to consider a range of reasons which may be provided as to why the correlative obligation could not immediately be realised: these could include questions relating to the scarcity or resources; the distribution of resources; the need not to disrupt existing programmes; the efficiency of ad-hoc orders; and the responsibility of Juana herself in her own plight. ${ }^{58}$ These factors will play an important role in determining ultimately which actions must be performed concretely to realise Juana's entitlements. At the same time, a crucial element of the court's work will need to consider the nature and capacity of the possible agents who can realise Juana's right. The allocation of obligations amongst these agents will be an important factor to consider for any effective defence of Juana's right. At this point, the competence, capacity and democratic appropriateness of a particular agent will play a crucial role.

What is evident from this example is that the adjudicatory task begins with the construction of a right separate from an understanding of what may be justifiable reasons to limit the right or institutional considerations as to the appropriate agents (within the state or without) that are necessary to realise it. ${ }^{59}$ This is important for a number of reasons: first, it allows an unalloyed understanding to develop as to what the rights in the constitution are meant to provide to individuals. If these are guarantees that protect the fundamental worth of every person, which interests are protected and which are not? What level of protection is afforded? Different answers may be provided rooted in considerations relating to a philosophical understanding of these interests, ${ }^{60}$ or perhaps some kind of social consensus or plan around such matters. ${ }^{61}$ Providing answers to these questions is crucial for several reasons: first, it enables individuals to understand what they may claim from their rights in the constitution. Secondly, it is hard to understand the claim that rights are in fact entitlements or protections without some understanding of 'what' they protect. It is thus necessary in order to have any meaningful sense of what these rights are and in fact guarantee. Finally, and most crucially in this context, it helps provide a clear understanding of the weight and significance of the interest that must be guaranteed which then allows for

\footnotetext{
58 I have developed in more detail factors relevant to moving from conditional rights to unconditional obligations in Bilchitz, supra note 32 at 83-91.

${ }^{59} \mathrm{See}$, the paper by Deva in this collection on the obligations of non-state actors in this area.

${ }^{60} \mathrm{I}$ have tried to outline such an approach in ibid 7-46.

${ }^{61}$ See K Young, Constituting Social AND ECONOMic Rights (2013) at 50-64.
} 
an evaluation of the justifiability of any reasons - institutional or otherwise - for not realising the right or realising it only partially. Without a clear understanding of what must be guaranteed and its importance, it becomes hard to see how the right can be provided with an appropriate weight in any reasoning exercise. It is hard to see how we can evaluate government reasons for the attenuation of obligations (which, as we saw, Jeff King sees as the primary task of courts in this field) if we do not first have an understanding of what the rights protect and the correlative general obligations in fact are. Determining the content of a right is thus essential not only to give rights the weight they deserve but also as an analytical precondition to a proper evaluation of governmental reasons for not immediately realising them.

One important point of clarification is necessary to understand what it means to specify the content of the right. As I've argued, what is key is to have a specification of the interests protected by the right and the general level of protection. Would this require the need to identify an exact quantitative amount of calories that would constitute sufficient food, for instance? In my view, that level of specification would be undesirable. The reason for this is that there is an empirical question to be determined as to the amount of calories that would be necessary to realise any set of general interests protected by a right. That amount of calories may also vary between individuals: pregnant women, for instance, may require a higher calorie intake to achieve the same level of functioning. ${ }^{62}$ What is critical is for a specification to be achieved as to the general standards that the constitution sets in relation to each entitlement: everyone is, for instance, entitled to the level of food necessary to be a healthy, functioning individual capable of achieving a wide range of purposes. The exact number of calories required to meet this standard is an empirical matter for determination by experts and is an example of a matter that courts in a system of judicial review can legitimately require the input of other branches of government on. Importantly, here, the input from other branches is desirable in order to flesh out an already specified constitutional standard; it is not an abdication of the responsibility to provide such a standard in the first place. Courts also may be required to evaluate whether the particular empirical determination meets the constitutional standard if there are good reasons provided by litigants that it does not.

When we turn to a consideration of the exact, specific obligations that must be fulfilled, as we have seen, there is room for a state to justify the attenuation thereof. Importantly, as we have seen, the provision of content to rights provides the point of departure and conditions the arguments that can be made in this regard and the ultimate balance to be achieved. The focus on obligations, as we have seen, brings in not only matters which justify the limitations on what must be done, but also, as a central matter of focus, the question of the agents that must realise these rights. It is at this point that institutional considerations relating to the separation of powers legitimately enter into the picture. If the failure on the part of the government relates to the need to pass legislation, then the legislature must be ordered to do so. If the failure relates to the lack of executive action and a failure of policy, then it will be target of the court's order. Whether national, provincial or local government is responsible will also be important matters for determination. Courts will here need to consider the respective expertise of the relevant branches, as well as which agent can ensure the most effective realisation of these rights. Separation of powers considerations thus may have an important instrumental dimension to play in the effective realisation of socio-economic rights.

\footnotetext{
${ }^{62}$ A SEN, Resources VALUES AND DEVELOPMENT (1984) at 510 makes this point in arguing for the capabilities approach.
} 
There may, however, also be principled or intrinsic democratic reasons relating to the separation of powers that may lead a court to defer decision-making around the concrete obligations flowing from a right to other branches. Importantly, if a court decides in this manner, it will have provided some content to the right and could require that that determination be taken into account in any decision-making by other branches. The substance of rights here would guide decision-making by other branches rather than itself being attenuated by the separation of powers concerns. Separation of powers may thus provide reasons for courts not to make all-things-considered decisions around what exactly must be done by particular agents and defer to their decision-making powers in relation to particular obligations that flow from rights given the complexity of the subject matter or the preference for democratically-elected branches to make such a decision. It does not provide any reasons for those branches to avoid giving effect to these rights and to making explicit the manner in which rights-related considerations have influenced and played a role in their decisionmaking powers. The point is that the separation of the issues relating to 'what' must be provided and 'who' must provide them applies equally to other branches as it does to courts. The deference of a court to another branch as to the exact nature of its obligations does not mean that the other branch can decide in whatever manner it likes: it still needs to provide reasons as to why the construal of its obligations is justifiable in light of what the right guarantees to individuals. If it cannot do so, its decision may, once again, be challenged in court.

There appears on its face to be a close inter-relationship between the enquiry into assessing the justifiability of the obligations assumed by other branches of the government and the reasonableness approach of the South African Constitutional Court - which seeks to evaluate whether the approach of these branches is reasonable. Yet, as we have seen, the problem is that Constitutional Court moves immediately to a consideration of obligations and appropriate agents without first engaging with a construction of the rights in question. As such, the reasonableness enquiry becomes detached from rights-based considerations which should be primary and, in fact, lacks coherence as to the very basis upon which the reasoning of the other branches can be evaluated. The approach I have argued for in this paper is one where grappling with the content of rights becomes primary and any justification for failing to realise the right must engage with that content, whether it be provided by courts or other branches of government.

\section{E. The Substance of Rights, Separation of Powers and the Role of the Judiciary}

It is important at this point to consider a key objection to the reasoning thus far which has argued for a sharp separation between considerations of 'what' a right guarantees and 'who' is to implement it. It may be contended that I have essentially begged the question in this paper as I have assumed that the judiciary itself should provide content to rights. With that assumption in place, of course, it becomes possible to argue that rights should be interpreted on a prima facie level unalloyed by separation of powers considerations. But, the problem is deeper than I have suggested: for, the most profound challenge is one that in fact questions the very role of the judiciary in the interpretation of rights. The argument would be that rights interpretation involves very profound matters upon which individuals in the society disagree: as such, they should not be determined by the judiciary but by the elected branches of government. ${ }^{63}$

The objection as stated is too strong and has very little purchase in a political system such as that of South Africa where the constitution itself provides for the powers of the

\footnotetext{
${ }^{63}$ The most famous exponent of this view is J WALDRON, LAW AND DisAGREEMENT (1999).
} 
judiciary to have the final say in the interpretation of rights. The 'who' question - in these countries - has already been determined by the constitutional system and the deeper philosophical debate around whether judicial review is justified has been resolved by the constitution itself. The critic, however, could respond that the tenor of the objection is not to remove the power of the judiciary to interpret rights but rather about affecting the manner in which the judiciary should exercise that power. Since it should recognise its own limitations of democratic legitimacy and competence, it should employ those powers only in circumstances which are either uncontroversial or where it could give effect to a determination of content that has already been provided by the legislature or executive. ${ }^{64}$ The question concerning 'who' is entitled to determine the content of rights thus either cautions that the judiciary refrain from making a decision or ensures that it adopts an approach to content already pronounced upon by other branches of government.

The starting point in responding to this objection is to recognise how far it takes us even if it is accepted. As stated, the objection does not provide grounds to conflate a determination of the content of a right with separation of powers considerations. If the judiciary should defer on a particular matter, then another branch of government is given the task to interpret the right. Clearly, there is a need for some kind of remedy if the legislature or executive fails to do so: it seems that the judiciary, at least, will have to order another branch of government to provide its understanding of what the right entails if it fails to do so on its own initiative. The circumstances envisaged in which the judiciary may pronounce on the interpretation of rights all relate either to providing content that is uncontroversial (separate from institutional considerations) or in situations where content has already been provided by other branches (which also, if the argument is followed, should be separate from institutional consideration). Thus, even if the objection is regarded as correct, it provides no grounds to conflate the determination of content (the 'what' question) with institutional considerations relating to the separation of powers (the 'who' question). Whether it is the legislature, the executive or the judiciary that provides such content - and there is no reason to see the interpretation of rights as the sole preserve of the judiciary even if one adopts a more expansive view of its powers - the institution that does so should focus on the interests the right is designed to protect which should condition what may be done and who is required to do it. The point I have sought to defend in this article is a conceptual one with strong practical implications and stands apart from one's views about the particular branch of government that is best suited to the interpretation of rights.

We may, however, be more bold and challenge the argument that the judiciary has such a limited involvement in rights interpretation at all. I do not wish to re-hash in any detail the lengthy discussion in philosophical and constitutional law literature concerning the justification of judicial review. There are clearly strong reasons that have been advanced for the judiciary to play a key role in the interpretation and defence of fundamental rights. ${ }^{65}$ The argument I wish to provide, following the theme of the paper, relates to the fact that understanding the very nature of what constitutional rights protect (the 'what' question) provides an important foundation for 'who' should interpret these rights. The 'who' question

\footnotetext{
${ }^{64}$ The approach adopted by the court in Mazibuko can be read this way. See also B Ray, Evictions, Aspirations and Avoidance, 5 Constitutional Court REview 172ff (2013) who understands much of the South African Constitutional Court's jurisprudence in this way as well as M Khosla, Making social rights conditional: lessons from India 8 INTERNATIONAL JOURNAL OF CONSTITUTIONAL LAW 739ff (2010) who makes a similar point about the Indian Supreme Court which has effectively only been prepared to provide content to rights where other branches have already spoken.

${ }^{65}$ For some of the arguments in this regard, see R DwORKIN, FREEDOM's LAw: THE MORAL READING OF THE AMERICAN CONSTITUTION (1996) chapter 1 and D BILChitz, Poverty AND Fundamental Rights (2007) chapter 4 .
} 
cannot, it shall be argued, be determined without some understanding of the nature and substance of these constitutional rights. Let me elaborate upon this argument.

Many modern constitutional systems, as we have seen, expressly recognise judicial review and the power of judges to interpret rights. The attempt to attenuate these powers requires some justification as to why it does not represent an abdication of the responsibility that is entrusted to the judiciary. If we take the objection articulated above seriously, it begins with an already determined vision as to what the appropriate role of the judiciary should be in respect of rights. How, though, are we to determine that role without a clearer idea of what rights in fact are and what they protect? It is hard to see how we are to decide about the decision-makers relating to rights if we lack an understanding of what rights are in a constitutional system. If the judiciary - in systems which already provide for judicial review - must provide an understanding of its role in interpreting rights, and in order to do so, it must have a certain conception of the nature and substance of what rights in fact are, then the judiciary - of necessity - must engage in some determination of the nature and content of these rights. Thus, where the question is not whether the judiciary should adjudicate on socioeconomic rights, but its approach and role in relation to such adjudication, it must of necessity adopt some substantive vision of these rights. That understanding of content is necessary for an understanding of how it should exercise its very adjudicatory powers. ${ }^{66}$ Thus, when determining a case on the right to adequate housing, a court cannot decide the manner of its intervention and what can legitimately be required of another branch of government without first capturing what is involved in the very protection of the right itself. Once that is determined, it may well find that it requires empirical evidence from experts based in another branch or that another branch will need to determine whether it is feasible to meet its obligations. It may legitimately defer at these points but not before recognising what the right in fact requires in terms of general principles derive therefrom.

This argument can be supported further by understanding the special role of constitutional rights in a legal system. Part of the very point of constitutionalised rights are that they have a higher status within a political system: that status means that they can override ordinary legislation and executive actions. The status of rights flows from their importance and the fact that they protect the most fundamental interests of individuals: they are really the foundation of the rest of the legal order. If the very bodies that pass ordinary legislation and executive actions are to be the primary institutions to give content to these rights, then it is hard to see the manner in which constitutional rights retain their higher status. The very status and role of constitutional rights within a legal order seems to require an institutional structure that reflects the fact that they are not placed on the same level as ordinary legislation/executive action. Their interpretation in some sense must be separate from the ordinary passing of legislation or executive conduct. That fact does not automatically justify placing the interpretation thereof in the hands of the judiciary: alternative structures such as special parliamentary committees or organs of the executive can be envisaged which could perform that task. The point is that, in the absence of such structures, the judiciary may be set up specifically to perform the function of adjudicating on these higher-status rights. Where that is the case, the very status and nature of fundamental rights within a constitutional system provides reasons why the judiciary should not outsource that interpretive function to other branches. 'What' constitutional rights are and 'what' they

\footnotetext{
${ }^{66}$ See Klatt, supra note 57 above 371-372 who recognises, in his model, that one of the key factors in determining the competence of the judiciary to decide a matter and the level of scrutiny it should exercise relates to the normative importance of the interests at stake in a particular case that are protected by a fundamental right.
} 
protect provide the reasons for 'who' - the judiciary - should be tasked with giving them content.

\section{CONCLUSION: RECONCEIVING SEPARATION OF POWERS AND CONTENT}

This paper has been concerned about the relationship between reasoning relating to fundamental rights and the separation of powers. I have tried to trace the manner in which institutional considerations in South Africa have influenced both the approach of courts towards the adjudication of socio-economic rights as well as the content that has been provided to such rights. ${ }^{67}$ I have argued that it mistaken conceptually as well as undesirable to conflate the content of rights with separation of powers concerns. There is, however, a relationship between the two sets of considerations and I attempted to capture this by distinguishing between reasoning founded in notions of fundamental rights and reasoning based in an understanding of obligations. The two are not equivalent, I contended: understanding this is key to recognising why parsing fundamental rights needs independent consideration whilst still recognising that, in determining concrete obligations, a number of agent-centred considerations do enter the picture. One of these relevant agent-centred factors would be questions relating to the separation of powers but these need to be guided by the content of rights that is developed.

The approach I have adopted in this paper places fundamental rights as the core substantive normative considerations underlying constitutional democracy. At the same time, it is necessary to consider the design of institutions that will best realise this substantive core. Institutional design has its own logic and there will be a range of reasons why some institutions succeed and others fail that are separate from rights reasoning. At the same time, what becomes clear is that the institutional considerations are at the service of ensuring the realisation of fundamental rights. If that is so, then we cannot seek to collapse the content of these rights with these institutional considerations and they have to be determined separately. Different branches of the state may well be involved in determining that content and this reasoning applies to all involved in that project. There are good reasons though - rooted in the very nature and content of constitutional rights - why the judiciary may have a central role to play in this area. Ultimately, the goal of institutional structures must be to ensure that the fundamental rights of individuals are realised. To do so, we must avoid fetishizing these structures and ensure that rights are accorded the attention they deserve.

\footnotetext{
${ }^{67}$ I have not outlined how this occurs in other constitutional systems though my research has shown that the point probably applies in many contexts including, particularly, India. See Bilchitz supra note 13 above at 81-93 and S FREDMAN, HuMAN RigHTS TRANSFORMED (2008) chapter 5.
} 